\title{
Monitoring State Of Charge Accumulator Berbasis Graphical User Interface Menggunakan Arduino
}

\author{
Rijeng Firanda ${ }^{1}$, dan Muldi Yuhendri ${ }^{2}$ \\ 1,2Jurusan Teknik Elektro, Fakultas Teknik Universitas Negeri Padang \\ Jl. Prof. Dr. Hamka Air Tawar, Padang, 25132 Indonesia \\ Rijengfiranda@gmail.com¹, muldiy@ft.unp.ac.id ${ }^{2}$
}

\begin{abstract}
Abstrak: Energy listrik merupakan sumber energi yang banyak digunakan dalam kehidupan sehari hari salah satunya aki. aki merupakan tempat penyimpanan sumber listirik yang praktis yang mudah dibawa dan digunakan sesuai kebutuhan sehari hari. Sedangkan jika aki dipakai terus menerus maka tegangan aki akan menjadi kosong, oleh sebab itu diperlukan pengisian ulang terhadap aki, agar aki dapat terisi dengan baik diperlukan pemantauan pada saat pengisian agar didapatkan hasil yang maksimal. Pada pemantataun pengisian aki ini meliputi, tegangan aki, suhu aki , tegangan panel surya sekaligus sebagai penyuplai tegangan untuk pengisian aki, dan mengunakan relai sebagai pemutus tegangan ketika Tegangan aki sudah terisi penuh supaya tidak terjadi kerusakan terhadap aki akibat kelebihan Tegangan yang masuk pada saat pengisian aki. Komponen yang dibutuhkan adalah sensor tegangan, sensor db18b20, relai . Semua komponen pada alat ini dikendalikan oleh Arduino yang dikoneksikan melalui Simulink untuk selanjutnya dikirim ke Gui Matlab sebagai tempat hasil pengujian berupa angka dan grafik.
\end{abstract}

Kata kunci: panel surya. Aki, relai, arduino, simulink Gui Matlab.

Abstract: Electrical energy is a source of energy that is widely used in daily life, one of which is battery. battery is a place to store a practical power source that is easy to carry and use according to daily needs. Whereas if the battery is used continuously then the battery voltage will be empty, therefore it is necessary to recharge the battery, so that the battery can be filled properly required monitoring at the time of charging in order to get maximum results. In the charging of this battery includes, battery voltage, battery temperature, solar panel voltage as well as a voltage supplier for charging the battery, and use the relay as a voltage breaker when the battery voltage is fully charged so that there is no damage to the battery due to excess voltage that enters at the time of charging the battery. The required components are the voltage sensor, db18b20 sensor, relay. All components in this tool are controlled by Arduino which is connected through Simulink to be sent to Gui Matlab as a test result in the form of numbers and graphs.

Keywords: solar cell. Acumulator, arduino, simulink, Gui Matlab.

\section{PENDAHULUAN}

Energi listrik merupakan sumber energi yang banyak digunakan untuk berbagai keperluan, seperti untuk penerangan, penggerak, pemanas dan sebagainya. Energi listrik ini dapat diperoleh dari berbagai macam sumber, seperti pembangkit listrik tenaga air, pembangkit listrik tenaga surya dan sebagainya. Berdasarkan jenis arusnya, energi listrik dapat dikelompokan atas arus searah atau direct current (dc) dan arus bolak balik atau alternating current (ac). Energi listrik ac umumnya dihasilkan oleh pembangkitpembangkit yang menggunakan generator ac, sedangkan energi listrik dc dihasilkan oleh pembangkit listrik tenaga surya, thermo elektrik, baterai, accumulator, fuel cell dan sebagainya.

Accumulator $(A c c u)$ adalah salah satu sumber energi listrik dc yang banyak digunakan untuk berbagai keperluan, seperti sumber energi listrik untuk kendaraan, penyimpan energi listrik pada pembangkit listrik tenaga surya dan sebagainya. Hal ini disebabkan oleh kelebihannya yang mudah dibawa, dapat menyimpan dan menyalurkan energi listrik sesuai dengan kebutuhan [1]. Асcu ini merupakan sebuah sumber energi listrik dc yang dapat menyimpan energi listrik dalam bentuk energi kimia pada sel-sel elektroda yang terdapat di dalamnya [2]. Energi kimia ini kembali berubah menjadi energi listrik ketika accu dihubungkan dengan beban listrik.

Secara sederhana, sebuah accu terdiri dari lempengan elektroda positif sebagai katoda dan lempengan elektroda negatif sebagai anoda. Diantara lempengan tersebut terdapat larutan elektrolit, dimana larutan elektrolit ini berbentuk cairan untuk accu basah dan berbentuk kering untuk jenis accu kering. Larutan elektrolit ini akan melakukan reaksi kimia terhadap lempengan elektroda, sehingga terjadi proses konversi energi listrik menjadi energi kimia saat proses penyimpanan energi dari sumber listrik ke accu, atau sebaliknya saat penyaluran energi listrik dari accu ke beban. Kemampuan accu menyimpan dan menyalurkan 
energi listrik ditentukan oleh ukuran dan jumlah lempengan elektroda yang digunakan serta kualitas elektrolit yang ada di dalamnya. Semakin banyak lempengan elektroda yang digunakan maka semakin banyaklah energi listrik yang dapat disimpan atau disalurkan.

Berdasarkan karakteristiknya yang dapat diisi ulang, maka accu ini dikelompokan sebagai baterai sekunder, yaitu baterai yang dapat diisi ulang. Pengisian energi listrik ke accu disebut dengan kondisi charging, sedangkan pelepasan energi listrik dari accu disebut dengan kondisi discharging. Karena kemampuan accu yang terbatas oleh elemen pendukungnya, maka pengisian accu harus memperhatikan beberapa parameter agar accu tidak cepat rusak, seperti parameter tegangan, arus, kapasitas, temperature dan sebagainya. Pengetahuan tentang karakteristik baterai menjadi faktor penting dalam kinerja system [3]. Banyak parameter yang perlu diperhatikan dalam pengisian dan pengosongan accu seperti tegangan, arus, suhu, resistivitas dan lain-lain. Pengisian accu yang melebihi kapasitas atau overcharging akan menyebabkan accu cepat panas dan akan menyebabkan larutan elektrolit akan mendidih pada accu basah. Hal ini akan memperpendek umur accu. Oleh sebab itu, status pengisian accu perlu dimonitoring agar accu tidak mengalami kerusakan pada saat pengisian. Status pengisian accu atau yang disebut juga dengan State of Charge (SOC) adalah rasio kapasitas energi yang tersedia dengan kapasitas energi maksimum pada baterai. SOC baterai ini dapat diketahui berdasarkan tegangan baterai pada rangkaian terbuka dan umumnya ditampilkan dalam hitungan persen.

Beberapa penelitian telah dilakukan untuk memonitor SOC baterei yang memonitor SOC baterai yang dilengkapi dengan fitur proteksi untuk memutuskan rangkaian pengisian ketika accu sudah penuh[4]. Selain itu SOC baterai untuk stasiun charging mobil listrik dengan menggunakan fuzzy logic untuk memprediksi SOC baterai berdasarkan perubahan tegangannya [5]. Penelitian lain tentang SOC baterai dilakukan oleh dilakukan yang membuat alat ukur SOC baterai lead acid 12 volt dengan kapasitas $12 \mathrm{Ah}$ menggunakan mikrokontroler sebagai pemproses data. [6]

Dalam penelitian ini dirancang SOC baterai berbasis Graphical User Interface (GUI) Matlab dengan menggunakan Arduino. Kelebihan dari rancangan ini adalah SOC dapat dilihat dalam bentuk angka dan grafik yang ditampilkan dalam satu layar monitor PC. Selain data SOC, dalam penelitian ini juga akan dimonitor tegangan dan suhu baterai. Sistem monitoring baterai yang dibuat dalam penelitian ini juga dilengkapi dengan proteksi overcharging baterai menggunakan relay yang akan dikendalikan oleh arduino. Arduino akan memutuskan kontak relay jika kapasitas baterai sudah penuh, sehingga baterai dapat terhindar dari overcharging. Baterai yang digunakan adalah baterai 45 Ah yang akan diisi dengan tegangan suplai dari panel surya menggunakan solar charger.

\section{Penelitian ini dilakukan dalam bentuk} eksperimen yang dimulai dengan perancangan, pembuatan dan pengujian menggunakan Simulink dan Gui matlab sebagai tempat hasil dari pengujian.

\section{Accumulator (Aki)}

Aki atau Storage Battery adalah sebuah sel atau elemen sekunder dan merupakan sumber arus listrik searah yang dapat mengubah energi kimia menjadi energi listrik. Aki terdiri dari aki basah, aki hybrid, aki calcium, aki bebas perawatan, dan aki sealed. Aki termasuk elemen elektrokimia yang dapat mempengaruhi zat pereaksinya, sehingga disebut elemen sekunder. Kutub positif aki menggunakan lempeng oksida dan kutub negatifnya menggunakan lempeng timbal, sedangkan larutan elektrolitnya adalah larutan asam sulfat. Ketika aki dipakai, terjadi reaksi kimia yang mengakibatkan endapan pada anode (reduksi) dan katode (oksidasi). Akibatnya, dalam waktu tertentu antara anode dan katode tidak ada beda potensial, artinya aki menjadi kosong.

Agar aki dapat dipakai lagi, harus diisi dengan cara mengalirkan arus listrik kearah yang berlawanan dengan arus listrik yang dikeluarkan aki tersebut. Ketika aki diisi akan terjadi pengumpulan muatan listrik. Pengumpulan jumlah muatan listrik dinyatakan dalam ampere jam, yaitu yang disebut dengan tenaga aki. Pada kenyataannya, pemakaian aki tidak dapat mengeluarkan seluruh energi yang tersimpan aki itu. Oleh karenanya, aki mempunyai rendemen atau efisiensi. [7]

\section{A. Charger accumulator}

Pada dasarnya charger adalah suatu alat yang digunakan sebagai pengisi ulang baterai atau tempat penyimpanan energi lainnya dengan melawan arus listriknya. Seiring dengan kemajuan teknologi maka ditambahkan pengatur/controller pada charger tersebut. Kegunaan dari charger controller adalah untuk mengatur energi yang masuk ke dalam beterai mencegah dari overcharging apabila baterai telah penuh, overvoltage, dan hal-hal lain yang dapat mengurangi umur baterai.[8] 


\section{B. GUI Matlab}

MATLAB (MATrix LABoratory) merupakan bahasa canggih untuk komputasi teknik. MATLAB merupakan integrasi dari komputasi, visualisasi dan pemrograman dalam suatu lingkungan yang mudah digunakan, karena permasalahan dan pemecahannya dinyatakan dalam notasi matematika biasa [9]

MATLAB telah menyediakan komponen yang berguna untuk mempermudah mendesain tampilan program. Sehingga dalam membuat program tidak diperlukan dalam penulisan kode untuk membuat tampilannya. Tampilan di dalam MATLAB dapat diatur dengan cara mengambil tools yang akan dipakai meletakan pada form yang sudah tersedia [10] berikut adalah tampilan GUI Matlab yang digunakan pada gambar.

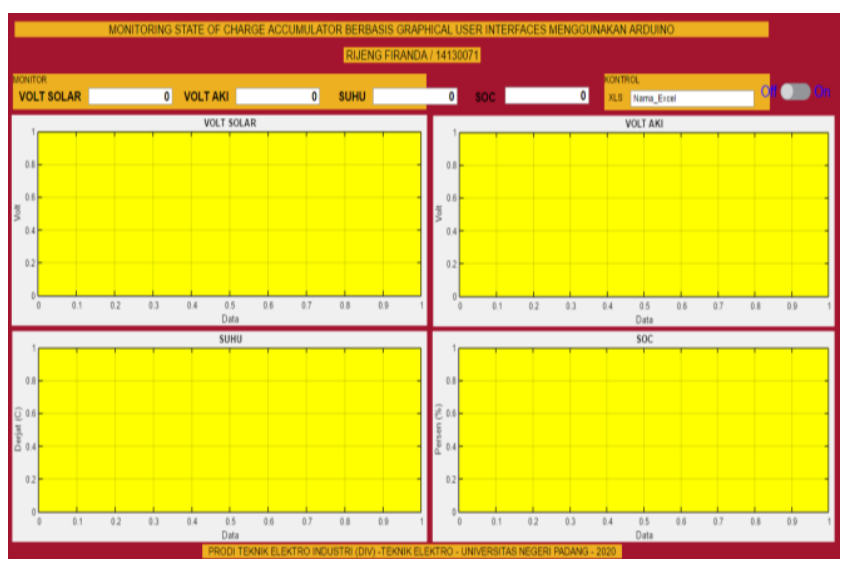

Gambar 1. Tampilan GUI MATLAB

\section{Arduino}

Arduino Uno adalah salah satu produk berlabel Arduino yang sebenarnya adalah suatu papan elektronik yang menganduk mikrokontroler ATmega328 (sebuah keping yang secara fungsional bertindak sebagai komputer). Peranti ini dapat dimanfaatkan untuk mewujudkan rangkaian elektronik dari yang sederhana hingga yang kompleks, bentuk dari Arduino uno sebagai berikut.

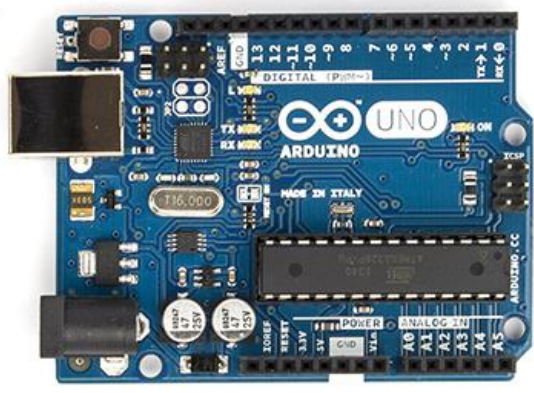

Gambar 2. Arduino Uno
Ardino Uno menganduk mikroprosessor (berupa Atmel AVR) dan dilenkapi dengan oscillator $16 \mathrm{MHz}$ (yang memungkinkan operasi berbasis waktu dilaksanakan dengan tepat), dan regulator (pembangkit tegangan) 5 Volt. Sejumlah pin tersedia di papan. Pin 0 hingga 13 digunakan untuk isyarat digital yang hanya bernilai 1 dan 0 . Pin A0 hingga A5 digunakan untuk isyarat analog [11].

\section{Sensor Tegangan}

Sensor tegangan yang digunakan merupakan sebuah modul sensor tegangan yang mengunakan prinsip pembagi tegangan. Modul ini dapat mengurangi tegangan input hingga 5 kali dari tegangan asli. Tegangan analog input maksimum mikrokontroler yaitu 5 volt, sehingga modul tegangan dapat diberi masukkan tidak melebihi 5 X 5 Volt atau sebesar 25 Volt. Modul sensor tegangan akan dipasang secara paralel terhadap beban panel surya [12]. Pada alat ini memiliki dua buah sensor tegangan yang masing masing digunkan untuk mengkur tegangan pada keluaran solar cell dan tegangan pada aki.

\section{E. Sensor Suhu}

Sensor yang digunkan dalah DS18B20 yang merupakan sensor suhu yang memiliki keluaran digital. DS18B20 memiliki tingkat akurasi yang cukup tinggi, yaitu $0,5^{\circ} \mathrm{C}$ pada rentang suhu $-10^{\circ} \mathrm{C}$ sampai $+85^{\circ} \mathrm{C}$. Sensor suhu pada umumnya membutuhkan ADC dan beberapa pin port pada mikrokontroler, namun DS18B20 ini tidak membutuhkan ADC agar dapat berkomunikasi dengan mikrokontroler dan hanya membutuhkan 1 wire saja. Gambar 2. Skematik Diagram Sensor Pada Gambar 2. ditunjukan bahwa pin ground dan Vdd dihubungkan dengan Vcc, sedangkan pin DQ dihubungkan dengan pin I/O pada mikrokontroler. Data yang dikeluarkan berupa data digital dengan nilai ketelitian $0,5^{\circ} \mathrm{C} .[13]$

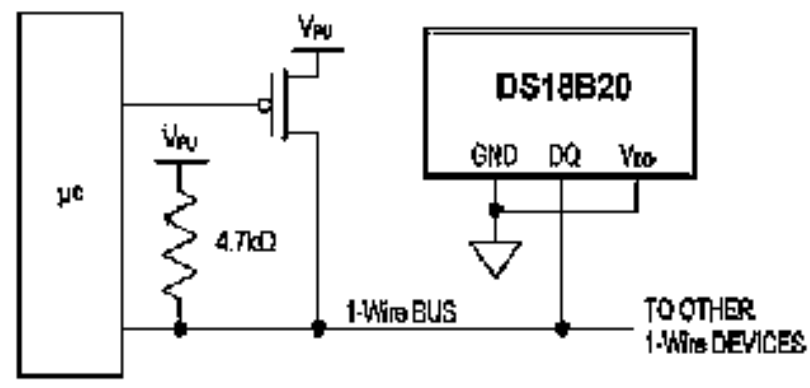

Gambar 3. Skematik Sensor Suhu 
Penelitian ini dilakukan dalam bentuk memonotiring status pengisian aki. State of Charge (SOC) merupakan suatu ukuran seberapa penuhnya muatan listrik dalam suatu baterai dalam persen (\%). Hubungan antara tegangan dengan SOC sangat bergantung pada temperature baterai. Baterai yang lebih rendah temperaturnya akan memperlihatkan tegangan yang lebih rendah pada kondisi penuh dibanding baterai dengan temperatur lebih tinggi[14].

Parameter baterai yang dimonitor adalah tegangan charger, tegangan baterai, suhu dan SOC baterai. Tegangan charger diukur pada output charger melalui sensor tegangan, dimana data sensor ini diolah oleh arduino, selanjutnya data tersebut ditampilkan dalam bentuk angka dan grafik dengan bantuan GUI Matlab. Data tegangan baterai diukur pada saat baterai dalam rangkaian terbuka atau terlepas dari rangkaian charger. Hal ini dalam dilakukan dengan mengatur waktu on off relay. data tegangan baterai diperoleh saat relay off, dimana saat itu rangkaian charger terputus dari baterai.

Data suhu baterai diperoleh dari sensor suhu yang ditempatkan pada baterai. Pada saat suhu baterai melebih rating suhu yang diizinkan untuk baterai tersebut, maka relay akan memutuskan rangkaian charger dari baterai. Data SOC diperoleh berdasarkan nilai tegangan baterai. Data SOC ini dipresentasikan dalam hitungan persen, sesuai dengan nilai tegangan baterai, dimana saat baterai dalam kondisi penuh, maka SOC nya bernilai $100 \%$. Semua parameter ini ditampilkan dalam bentuk angka dan grafik pada GUI Matlab. Data parameter-parameter yang dimonitor ini akan divalidasi dengan acuan data yang ditampilkan pada solar charger. Bagian bagian dari monitoring aki dapat dilihat pada gambar berikut:

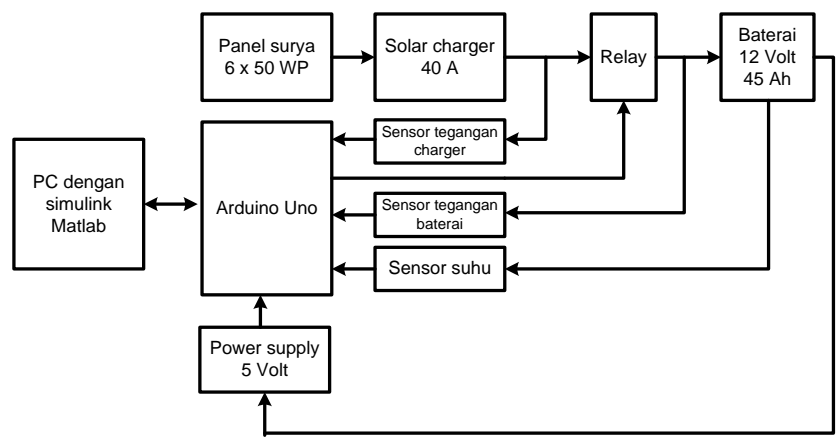

Gambar 4. Blok Diagram

Perancangan hardware terdiri dari perancangan mekanik dan perancangan elektronik. Perancangan mekanik yaitu membuat perancangan bentuk fisik dari alat monitoring itu sendiri dan perancangan elektronik yaitu membuat rangkaian elektronika yang akan direalisasikan ke bentuk PCB (Printed Circuit Board). Perancangan hardwere sebagai berikut:

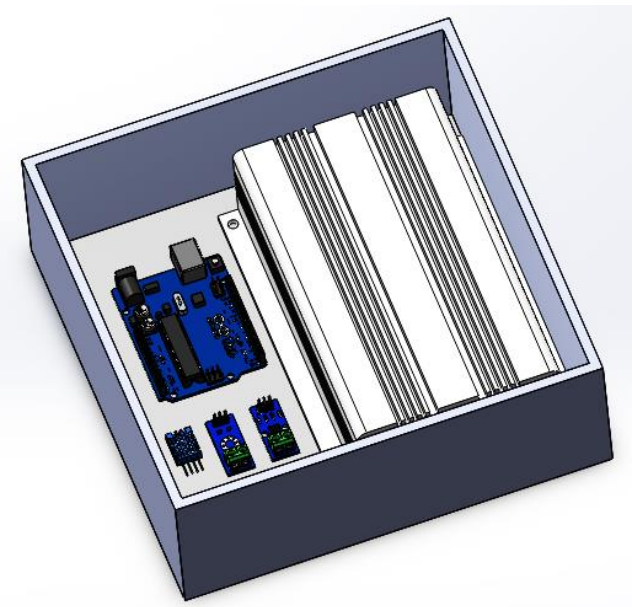

\section{Gambar 5. Kotak Pengontrolan}

Perancangan softwere dijalankan oleh Simulink MATLAB yang kemudian akan diolah oleh GUI MATLAB dalam bentuk angka dan grafik. Simulink adalah sebuah modul dari matlab yang dapat digunakan untuk mensimulasikan sistem dinamik dengan cara grafis yaitu dengan diagram blok, sistem dinamik dapat dimodelkan dengan diagram blok, panah sinyal, summing junction, blok gain, source dan sink [15]. Simulink dapat dilihat pada gambar berikut:

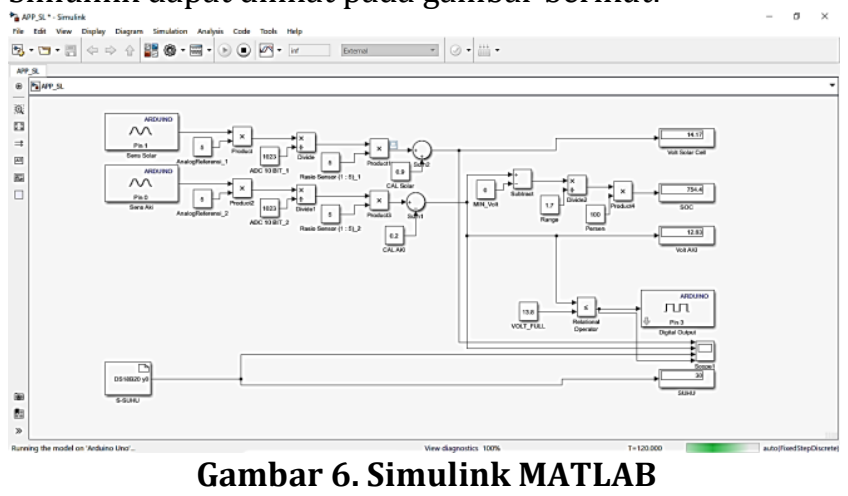

\section{HASIL DAN PEMBAHASAN}

Bentuk keseluruhan alat monitoring aki ini menggunakan solar cell sebagai sumber teganggan yang di alirkan melalui solar charger yang kemudian dihubungkan ke kotak rangkaian. Kotak rangkaian ini terdiri dari Arduino dip 328, dua buah sensor tegangan, sensor suhu, relay, dan menggunakan rangkaian catu daya sebagai penyuplai tegangan ke Arduino, selanjutnya semua rangkaian dihubungkan ke PC dengan menggunakan kabel USB untuk di olah GUI MATLAB dan dilakukan proses pembacaan grafik dan angka. 


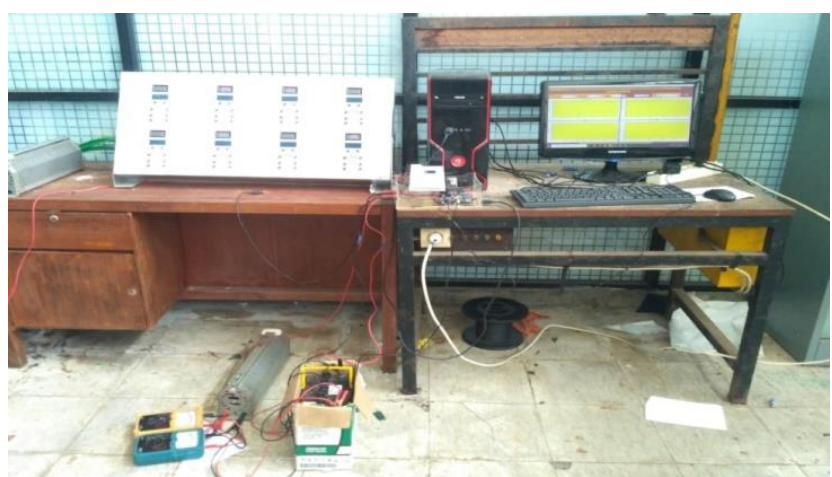

Gambar 7. Bentuk keseluruhan alat

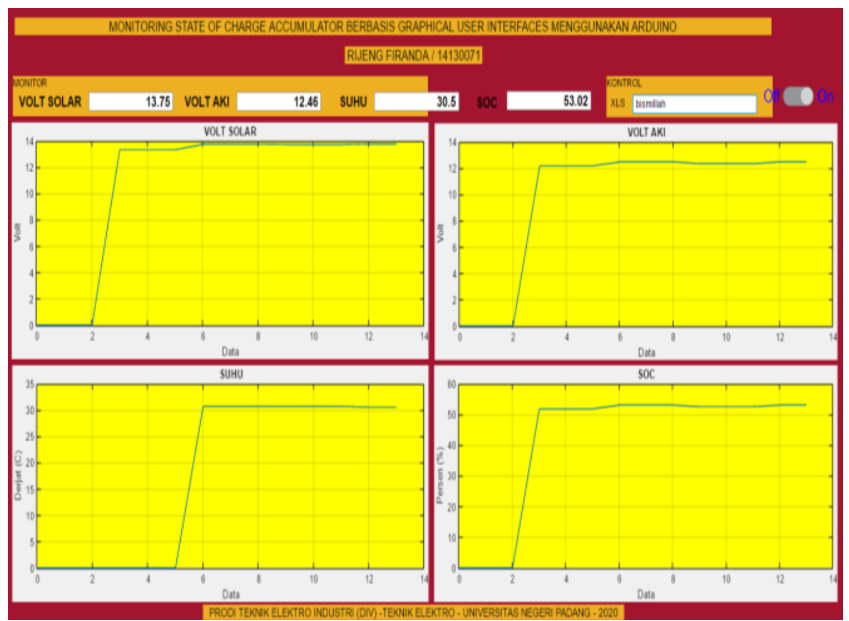

Gambar 8. Gui Matlab Tampa Beban

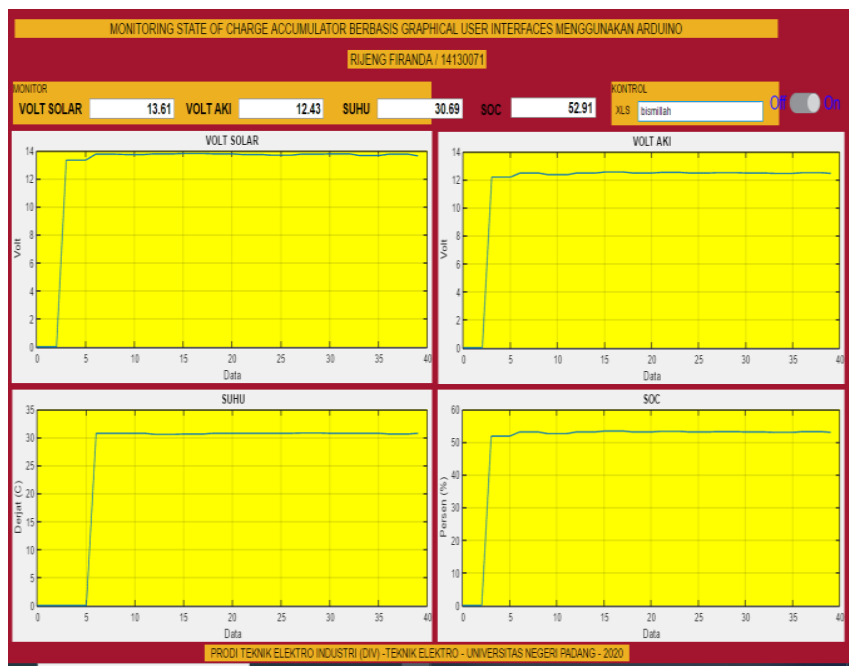

Gambar 9. Gui Matlab dengan beban

Pada gambar 8 dapat dilhat hasil dari pembacaan Gui Matlab, data yang telah di jalankan oleh Simulink untuk kemudian di proses menjadi grafik dan angka. merupakan hasil dari pembacaan gui matlab tampa beban. Pada gambar 9 dapat dilhat hasil dari pembacaan Gui Matlab, data yang telah di jalankan oleh Simulink untuk kemudian di proses menjadi grafik dan angka. merupakan hasil dari pembacaan gui matlab degan memakai beban, dan tampak bahwa persentase dari SOC menjadi menurun, dapat dilihat perbandingannya pada tabel 1 dan tabel 2.beban yang digunakan adalah resistor dapat dilihat pada gambar 10 .

\begin{tabular}{|l|l|l|l|}
\hline Volt Solar & Volt Aki & Suhu & SOC \\
\hline 13,75 & 12,46 & 30,5 & 53,02 \\
\hline
\end{tabular}

Tabel 1. tampa beban

\begin{tabular}{|l|l|l|l|}
\hline Volt Solar & Volt Aki & Suhu & SOC \\
\hline 13,61 & 12,43 & 30,69 & 52,91 \\
\hline
\end{tabular}

Tabel 2. memakai beban
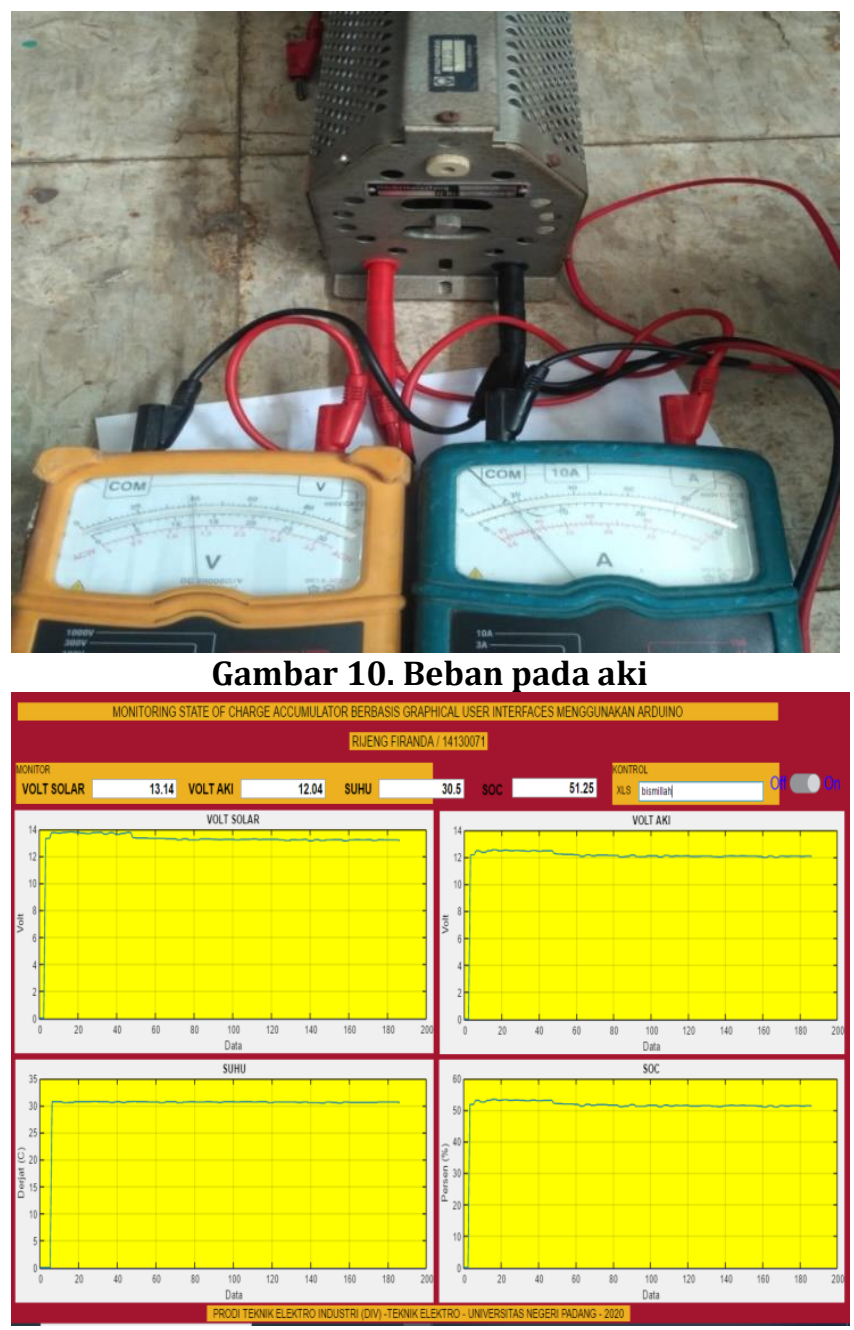

Gambar 11. Gui Matlab pakai beban tanpa menggunakan solar cell 
Pada gambar 10 dapat dilhat hasil dari pembacaan Gui Matlab, merupakan hasil dari pembacaan gui matlab degan memakai beban tampa menggukan solar cell, dan tampak SOC menurun dapat dilihat pada tabel 3 karena tidak mendapat suplay tegangan dari solar cell.

\begin{tabular}{|l|l|l|l|}
\hline Volt Solar & Volt Aki & Suhu & SOC \\
\hline 13,14 & 12,04 & 30,5 & 51,25 \\
\hline
\end{tabular}

Tabel 3. memakai beban tampa solar cell

\section{PENUTUP}

Penelitian ini dilakukan dalam bentuk memonotiring status pengisian aki (SOC). Parameter baterai yang dimonitor adalah tegangan charger, tegangan baterai, suhu dan SOC baterai. Tegangan charger diukur pada output charger melalui sensor tegangan, dimana data sensor ini diolah oleh arduino, selanjutnya data tersebut ditampilkan dalam bentuk angka dan grafik dengan bantuan GUI Matlab. Alat ini sudah bekerja dengan baik, apabila sedang dilakukan pengsian aki dan aki diberikan beban maka kinerja aki akan menurun, begitu juga ketika solar cell di putus maka tegangan aki juga ikut turun, karena tidak mendapat suplay tegangan dari solar cell dapat dilihat dari table 1,2, dan 3 .

\section{REFERENSI}

[1] Farizy, A., F., Asfani, D. A., Soedibjo. 2016. “Desain Sistem Monitoring State Of Charge Baterai Pada Charging Station Mobil Listrik Berbasis Fuzzy Logic Dengan Mempertimbangkan Tempera1tur". Jurnal Teknik Its. 5(2): 2301-9271.

[2] Aya, M. 2014. "Pengertian Dan Fubgsi Batrai (Aki/Accu)". (Online). Https://MoalAya.Blogspot.Com/2014/08/Pengertian-Dan-Fungsi-BatraiAkiaccu.Html. Diakses Pada Tanggal 11 Agustus 2019.

[3] Segara, A. P. B., Riawan, D. C., Suryoatmojo, H. 2013. “ Monitoring Kinerja Baterai Berbasis Timbal Untuk Sistem Photovoltaic". Jurnal Teknik Pomits. 1(1): 1-6.

[4] Bori, A. 2017. Sistem Monitoring Pada Alat Pengisian Baterai Otomatis (Tugas Akhir). Yogyakarta: Universitas Sanata Dharma .

[5] Farizy, A., F., Asfani, D. A., Soedibjo. 2016. "Desain Sistem Monitoring State Of Charge Baterai Pada Charging Station Mobil Listrik Berbasis Fuzzy Logic Dengan Mempertimbangkan Tempera1tur". Jurnal Teknik Its. 5(2): 2301-9271.
[6] Bayu, A., Darmawan, D., Qurthobi, A. 2017. "Perancangan Dan Implementasi Alat Ukur State of Charge Sistem Pengawasan Pada Baterai Lead AcidMenggunakan Metode Open Circuit Voltage". E-Proceeding Of Engineering. 4(1): 752-760.

[7] Kosasih, D. P. 2018. "Pengaruh Variasi Larutan Elektrolite Pada Accumulator Terhadap Arus Dan Tegangan". Mesa (Teknik Mesin, Teknik Elektro, Teknik Sipil, Teknik Arsitektur), 2(2), 33-45.

[8] Setiawan, B. 2016. "Sistem Pengisian Aki Dc 12 Volt Dari Panel Surya Menggunakan Algoritma Pwm Berbasis Arduino Uno". Jurnal Multimedia 7(1) : 45-50

[9] Rustamaji, Heri. 2017. Pengantar Komputasi Teknik Kimia Dengan Matlab Dan Simulink. Lampung: Aura

[10]Priatmoko, Andi. Harahap, Erwin. 2017. “Implementasi Algoritma Des Menggunakan Matlab". Jurnal Matematika 16(1)

[11] Fernandes, R. 2020. Rancang Bangun Solar Tracker Berdasarkan Waktu Pergerakan Mataharai Berbasis Arduino Uno. Tugas Akhir. Padang: Unp

[12] Fachri, M. R., Sara, I. D., Dan Away, Yuwaldi. 2015 "Pemantauan Parameter Panel Surya Berbasis Arduino Secara Real Time". Jurnal Rekayasa Elektrika, 11(4) : 123128

[13] Nurazizah, E., Ramdhani, M., Rizal, A. 2017. "Rancang Bangun Termometer Digital Berbasis Sensor Ds18b20 Untuk Penyandang Tunanetra". E-Proceeding of Engineering : 4(3) 3294-3301

[14] Ruskardi, 2015. "Kajian Teknis Dan Analisis Ekonomis Plts Sistem Terpusat Sebagai Energi Alternatif". Jurnal Elka.

[15] Safaruddin, M. 2015. Pengenalan Matlab dan Simulink. Program Studi Teknik Mesin Sekolah Tinggi Teknologi Mandala

\section{BIODATA PENULIS}

Rijeng Firanda, lahir di Kajai pada tanggal 24 Mei 1995. Saat ini sedang menyelesaikan program sarjana sain terapan DIV Teknik Elektro Industri di Jurusan Teknik Elektro Fakultas Teknik Universitas Negeri Padang.

Muldi Yuhendri, dilahirkan di Agam pada tanggal 13 Desember 1981. Menyelesaikan program Sarjana di jurusan teknik elektro Universitas Negeri Padang pada tahun 2005 dan program S2 di ITS Surabaya pada tahun 2009 serta S3 Ilmu Teknik Elektro pada tahun 2017 di kampus yang sama. Bekerja sebagai staf pengajar di jurusan teknik elektro Universitas Negeri Padang sejak tahun 2006 sampai sekarang. 